\title{
Managing the Profitability Performance of the Banks: Exploring the Antecedents through Case Examination of MCB Bank
}

\author{
Maria Shaikh ${ }^{1}$, Sumra Shaikh ${ }^{2,}$, Ghazala Benghal ${ }^{1}$, Haseeb Haleem Shaikh ${ }^{3}$ and Nadeem \\ Juman Shah ${ }^{1}$ \\ 1University of Sindh, Jamshoro, Pakistan \\ maria.shaikh@usindh.edu.pk; ghazala@usindh.edu.pk; syed.nadeem@usindh.edu.pk \\ ${ }^{2}$ Shaheed Zulfikar Ali Bhutto Institute of Science and Technology, Hyderabad Campus, Pakistan \\ sumra.shaikh@hyd.szabist.edu.pk \\ ${ }^{3}$ Universiti Tun Hussein Onn Malaysia, 86400 Parit Raja, Batu Pahat, Johor, Malaysia \\ haseeb_shaikh53@yahoo.com \\ ${ }^{*}$ Correspondence: sumra.shaikh@hyd.szabist.edu.pk
}

\begin{abstract}
Received: $9^{\text {th }}$ May 2020; Accepted: $20^{\text {th }}$ July 2020; Published: $1^{\text {st }}$ August 2020
Abstract: Debt financing has been used as an instrument of filling the budget deficits both in the private and public sector. Over the years it has gained popularity and it is now a common phenomenon to find in the finical reports of most companies' extent of debt. The contribution Advances and deposits are crucial for all banks. This research is aimed to judge impact of debt, investments, Advances, Equity, Taxes and deposits on profitability of banks. This research is aimed at identify impact of major factors on profitability of Muslim commercial bank of Pakistan (MCB) covering the period from 2011 to 2016 Secondary data was used from annual financial reports and from the website of Muslim commercial bank of Pakistan (MCB) and state bank of Pakistan. This research study is descriptive and correlative in nature. The data then analysed through multiple regression analysis in electronic views (e-views) in order to measure if there exists any relationship between bank profitability and leverage. Debt, Advances, Investment Equity and Taxes selected as independent variables and profitability as dependent variable in order to examine the effects of debt, Advances, Equity and Taxes on firm performance. The findings of the research are significant as per hypothetical relationship. The study revealed that bank advances, investments and equity has a positive effect on profitability whereas Taxes affects negatively to the profitability of MCB. The regression results show that Advances, Investments and equity which is independent variable is significant variable of profitability the dependent variable. Its significant at.000 level of significance as the p-value shows.
\end{abstract}

Keywords: Management; Debt Financing; Profitability; Firm Performance; Banks

\section{Introduction}

An entity which is engaged in the exchange of money and provides all monetary solutions, whose major activity is lending and receiving deposits is called bank. It receives money from those whose want to save and lent to those who need it. Thus, bank plays an important role in the growth and development of the economic sector of any nation (Allen et al., 2015). Organization cannot achieve their goals without satisfying their customers and employees therefore satisfying all customers is their first priority (Shaikh, Shaikh \& Shaikh, 2019a). Banks always give profit and services to their country as well as boost the economy of the country (Shaikh, Shaikh \& Shaikh, 2019b). Every organization or bank's very first and important aim is to earn more and profit. Profit can be defined as is the amount which 
can be found by deducting all expenses from revenues. The banks lend (give debts) to other organizations and charge the interest from increasing the profit. Debt considered as the amount which the company, organization, or a person borrow from the bank or even from friends and family, but in future the party which lend the amount to other party will charge with some interest. The person who lends money to the other party is known as creditor and the person who receives the money is called debtors, in simple words, the creditors always receive the amount of interest from the debtor. The interest rates vary from time to time to the agreement; the party can be bound to pay interests at the time otherwise the rate will increase. For example, a person borrows 10000 with the interest rate 2 percent with a maturity of six months. If the person is unable to pay money in time the interest rate will be doubled.

The financial position of a bank said to be good if the profitability ratio of bank is higher, the financial position of a bank is said to be bad if profitability ratio of bank is low. It happens when banks are unable to collect bank amount of debt, which is given to the person, the how bad debt amount will affect the profitability of banks.

\section{Background of the Study}

Banking sector has attracted significant scholarly attention over the past few decades (Galdeano, Ahmed, Fati, Rehan \& Ahmed, 2019; Umrani, Kura \& Ahmed, 2018; Umrani, Mahmood \& Ahmed, 2016; Khalid, Pahi \& Ahmed, 2016). Therein, debt financing comprises of main sources of external funding for most banks. It provides a mechanism of filling financing deficits for banks that have insufficient financial resources. Over the years, it has gained prominence as a result of pushing up the level of its usage and uptake. For example, in Pakistan, according to the state bank of Pakistan, debt financing is estimated to account for $90 \%$ of external financing. Debt financing has, over the years been utilized to fund capital expenditure, and in recent years more options and packages to finance general operations have been developed. The effect of debt financing on banks profitability is of considerable importance to all banks. Banks are Keen to Know about Advances, Equity, and its impact on profitability. The government of Pakistan through state bank have also required banks to increase their capital base has also necessitated this study. Banks typically play a significant role in every economy (Ahmed, Khalid, Ammar \& Shah, 2017). Currently, most of the banks have engaged in the expansion program, which requires huge some of the capital. Previous research studies have found debt having positive, negative and also both effects on the financial performance of banks. The research gap was discovered on the fact that previous studies have been focused on looking for the optimal proportion of capital structure and not on debt financing. Lack of studies on debt financing and profitability of banks and the concentration of studies on capital structure of banks have motivated my study, this made me to do study on impact of debt financing on profitability of banks, and we will analyze the impacts of debt financing on the profitability of Muslim commercial bank of Pakistan.

Different scholars have researched in the different section and variables affecting bank profitability, in this research paper we will study the impact of level of advances, Investments, Equity and Taxes on profitability of banks and we have selected one bank, the Muslim commercial bank of Pakistan formerly known as (MCB). We will take five years' ratio of profitability and equity capital, Advances, Investments and Taxes from 2011 to 2016 and analyze them.

\section{Research Questions}

1. How Investments, Advances, Equity, and Taxes impact the profitability of banks.

2. What is the impact of Advances on the profitability of Muslim Commercial Bank of Pakistan?

3. What is the impact of Investments on the profitability of Muslim Commercial Bank of Pakistan?

4. What is the impact of Equity on the profitability of Muslim Commercial Bank of Pakistan?

5. What is the impact of Taxes on the profitability of Muslim Commercial Bank of Pakistan? 


\section{Significance of the Study}

This research is a significant addition in the existing amount of knowledge on factors affecting bank profitability. This research on a mix of funds utilized by the banking sector and specifically (MCB) will help identify how the banking sector of Pakistan can determine its optimal capital structure. This research study will further help Capital markets, debts markets and government to make policies, fixation of interest rate and in multiple other ways. The research will also contribute to provide information to regulatory organizations that remain engaged in promoting investments such as Capital Markets Authorities in Pakistan to assist in analyzing and harnessing financial resources relevant to business and form policies that foster investments in developing countries. The study will be assistance to management, which further helps firms in an attempt to improve and make decision making processes more effective and as a result, help firms maximize their shareholder value. The end results of this research will also assist Entrepreneurs, Institutions to make more effective decisions regarding investments.

Banking Industry is to obtain information on the relationship between Capital Advances, investments, Taxes, and profitability. This information will be especially useful to future investors in the industry and Senior Management. Cheaper business financing opportunities through the issuance of medium- and long-term firm's bonds would help in the containment of cost of debt and improve shareholder value. The Government is to obtain information on the importance of implementation of various legal frameworks in relation to Capital management. The academicians in the fields of Finance, Accounting and Investment are to benefit from this research as it shall provide them with various important facts. To finance academicians, the finding is to shed some light on corporate bond market characteristics in the Pakistan stock market and further be studied in the future. For the Accountants, they are to gain an inside on how the accounting factors count much on the decisions about investing in a firm.

The investment scholars, from the finding, they are to get an understanding of the relationship between risk and return. How the development of debt finance is to help in wealth diversification and management in addition to contributing to the body of knowledge, the research also helps and encourages continuity as far as doing further research is concerned. Regulatory bodies like the State Bank of Pakistan will further acknowledge the importance of Capital Adequacy in management in banks.

\section{Theoretical Framework}

In this portion of the study, we have discussed the theory related to our study, the trade-off theory, pecking order theory are discussed below.

\subsection{The trade-off Theory (TOT)}

One of the famous theories on leverage financing introduced by Modigliani and Miller 1958, the theory states that the benefit can be extracted from leverage financing up to a level of debt until the optimal capital structure is reached. The tradeoff theory emphasizes on Tax benefit of leverage. According to most of the previous researchers, as found through the literature majority of the firms utilizes less than optimal level of debt finance. The tradeoff theory has roots in the (1963) proposition of Modigliani \& Miller. According to TOT the firm value is maximized by $100 \%$ utilization of debt, but there are many theories and studies that suggest $100 \%$ debt utilization is not practical; there are multiple factors that restrict $100 \%$ debt utilization and thus make the model incomplete in its predictions. One of the major factors affecting most of the use of debt in capital structure is bankruptcy costs. According to Kraus and Litzenberger (1973), the optimal level of debt in capital structure can be obtained by the trade-off between the tax shield and Costs arising from debt enhanced leverage and riskier activities. According to TOT the value of the firm maximizes up to the extent to which bankruptcy costs is lower than the tax benefit derived from use of leverage; thus firm can identify the optimal debt to equity ratio, keeping in view the tax cost benefits. Myers and Majluf (1984) in their study also hypothesized that 
debt and equity choices are dynamic processes and based on multiple factors and are nit static processes.

\subsection{Pecking order Theory (POT)}

Myers and Majluf (1984) developed the pecking order theory or pecking order model (POT), and it states that upon the asymmetry of information between internal stakeholders (owners and managers) and external providers of the firm. Usually, the leaders of business adopt a financial policy, that aim of that policy is to increase the cost of financing with asymmetric information, that it states that cost of financing increases with asymmetric information, when it comes to methods of raising capital, the firm will perform financing that comes from three sources, internal financing, debt, issuing new equity usually considered as last resort, they perform internal financing. First, debt second and then issuing new equity is last.

Mayer argues over the hierarchal distribution of capital sources. And he claims that firms should prefer to utilize internal sources of financing rather than external sources. Further, he suggests that debt financing, considered in return, is usually superior to equity, as equity issuance is considered least preferable for profitable firms. Simply generate sufficient internal sources to finance their investments. In 1984, Myers and Majluf suggested that if asymmetric information between managers and investors would require the company to follow the capital structure of the pecking order model if they want to signal its attractiveness to the market.

\section{Literature Review}

Gul et al. (2011) from university of vasa and did qualitative research and he found that public debt financing may have negative effect on firm's market valuation, firm's that rely on public debt underperform relative to firms with other sources of debt financing in terms of stock market valuation and further his research results shows that firms, which entirely rely on bank debt performed better than the firms with public debt.

Javaid et al. (2011), researched the financial performance of companies listed at the security exchange, and she used quantitative research design by his findings of research revealed that short term debt was negatively correlated to return on assets, but not significantly, and long term debt was also negatively correlated to return on assets but less significantly than short-term debt. and also he found that there was a weak negative correlation between return on assets and total debt with a correlation of -0.337 , and according to his research debt has no significant influence on profitability, either in a linear way or in non-linear way, but recommended that firms should use more long term debt since there is a less negative impact on financial performance.

Accordingly, Bashir (2003), they used secondary data, and they found that short term loan ratios have a significant negative relationship with both profit margin ratio and return on assets. However, they found that long term loan ratios on profit margin ratios had an insignificant positive relation was found, but the return on assets was establishing an insignificant negative association. Furthermore, they found that an insignificant positive relationship was established between trade credit and profit margin ratio and a positive relation was found with return on assets.

Khawaja et al. (2006) found and concluded in his research that a positive relationship between short term Advances and profitability and a negative association was established between long term debt and profitability and furthermore, his research showed that using to the less cost incurred on obtaining short term loans than long term loans and banks should go for short term loans.

Alexiou and Sofoklis (2009) research is based on quantitative method, and their research analysis showed that debt financing and profitability have a negative yet no significant relationship. Furthermore, their results recommend that $51 \%$ of total assets in the Nigerian industrial sector are represented by debt, confirming that, they are capital intensive and highly geared institutions, whereas profit ratio was only $3 \%$ of total assets in the sector.

Accordingly, Obamuyi (2013) conducted quantitative research and the results show that there is a positive relationship between short term debt and profitability of banks, to the total results, interest 
coverage ratio and size of the banks. However, profitability is negatively related to the long-term debt to total assets, total debt to total assets, and debt to equity ratio. And his regression results show the beta coefficient is positively significant for short term debt to total assets and negatively significant for long term debt to total assets to total debt to total assets and debt to equity ratio with profitability. Raheman et al. (2007) took secondary data, and they have explained the summary of results that the credit management will be insufficient, then the amount of bad debt portfolio will be higher, which causes dilution in profitability.

\subsection{Debt financing}

Debt financing, one of the major determinants of profitability, is the money borrowed from a lender, at a fixed rate of interest and with a maturity date. In finance debt, also referred as "leverage", banks are considered the most popular source of debt financing, but debt can also be issued by a friend, family member or by a private company (Cole \& Sokolyk, 2016). Talking about its advantages, debt financing provides you the complete freedom, and there exists no control problem. Similarly, the tax deduction is one of the biggest expenses on the business, and it can be minimized with the use of debt capital in the business. The interest payments help minimize the tax burden on the firm. Alongside this, as a banker and investor, if you compare the corporate tax rate and the interest prevailing in the market, you can better make a decision about whether to use debt financing. If government-corporate taxes are flate $35 \%$ and interest charges are 15\%. Importantly, there are disadvantages of debt financing as well. For instance, new startups may find it difficult to secure debt finance because bankers are conservative when lending money. Accordingly, rates will vary with the economic condition your history with the banks and your personal credit history. Likewise, one must be sure that the firm is capable of generating enough cash to service the debt. If your organization fails, you are still obliged to repay your debts. Also, organizations sometimes face cash flow shortages that effect regular payments (Pham \& Nguyen, 2020).

\subsection{Profitability}

Raheman, Zulfiqar and Mustafa (2007) asserted that profitability is considered as the primary goal of every organization; without profitability business will not survive in the long run. Measurement of profitability is very important, profitability can be measured with income and expenses and income is generated from the activities of business, highly profitable business has the ability to reward, its owners with a huge return on investment. Every organization is most concerned with its profitability. One of the most frequently used tools of financial ratio analysis is profitability, Profitability known as the ability of an organization to generate revenues using its all resources in excess of its expenses. In other words, this is a firm's capability of generating profits from its operations.

In this research study, there are two variables one is dependent, and another is independent, the debt financing is independent, and profitability is dependent. To measure the relationship between debt financing and profitability, the Regression model was used to analyze data and it is collected from the annual financial reports of the MCB. Regression analysis is a statistical tool used for investigating the relationship between variables.

\section{Hypotheses development}

$\mathrm{H}_{0}=$ profitability/ RoA.

$\mathrm{H}_{1}=$ loan/advance have a positive impact on bank profitability.

$\mathrm{H}_{2}=$ total deposits have a positive impact on the profitability of bank.

$\mathrm{H}_{3}=$ equity has a positive impact on the profitability of bank.

$\mathrm{H}_{4}=$ investment has a positive impact on the profitability of bank.

$\mathrm{H}_{5}=$ tax has a negative impact on the profitability of bank; the only factor in this study to estimate the negative impact on profit of the bank 


\section{Research Methodology}

In this research, the study employed secondary data, which is collected from annual reports of Muslim commercial bank of Pakistan (MCB) and web site of State bank of Pakistan. And five years of data is collected (2011-2016) to analyze the impact of debt financing on the profitability of the Muslim commercial bank of Pakistan (MCB), and the research study is descriptive and correlative in nature. The research study applied multiple regression method in electronic views (E-views) to analyze the impact of debt financing on profitability.

\subsection{Population and Sample Size}

According to Mugenda and Mugenda (1999), a target population is one the researcher wants to generalize the result of the study. Therefore, in this research study, the population is selected for the study as the sample, is Muslim commercial bank of Pakistan (MCB), and covering the five years period (2011-2015), data which is selected for research as the size of the study to analyze the variables.

\subsection{Sampling Technique}

Since the population of the study is not very large, the study was a census and thus, the researcher focused on the whole population. The study was employed on the Muslim commercial bank of Pakistan (MCB) and took five years of data (2011-2015) to analyze the variables. There are two sample techniques, which are used to analyze variables first in MS EXCEL to analyze the ratios of leverage and profitability of bank and secondly data put in Electronic views (EVIEWS) software for multiple regression analysis for the analysis of the relationship between debt and profitability and differences between them.

$$
\begin{aligned}
& \mathbf{Y}=\mathbf{a}+\mathbf{b}_{1} \mathbf{X}_{1}+\mathbf{b}_{2} \mathbf{X}_{2}+\mathrm{b}_{3} \mathbf{X}_{3}+\mathbf{b}_{4} \mathbf{X}_{4}+\mathbf{b}_{5} \mathbf{X}_{5} \\
& \text { - } \mathrm{Y}=\text { profitability of bank } \\
& \text { - } a=\text { constant } \\
& \text { - } b=\text { beta/coefficients of their relative variables } \\
& \text { - } \mathrm{x}_{1}=\text { investment } \\
& \text { - } \mathrm{x}_{2}=\text { equity } \\
& \text { - } \mathrm{x}_{3}=\text { advances } \\
& \text { - } \mathrm{x}_{4}=\text { taxes } \\
& \text { - } \mathrm{x}_{5}=\text { deposits. }
\end{aligned}
$$

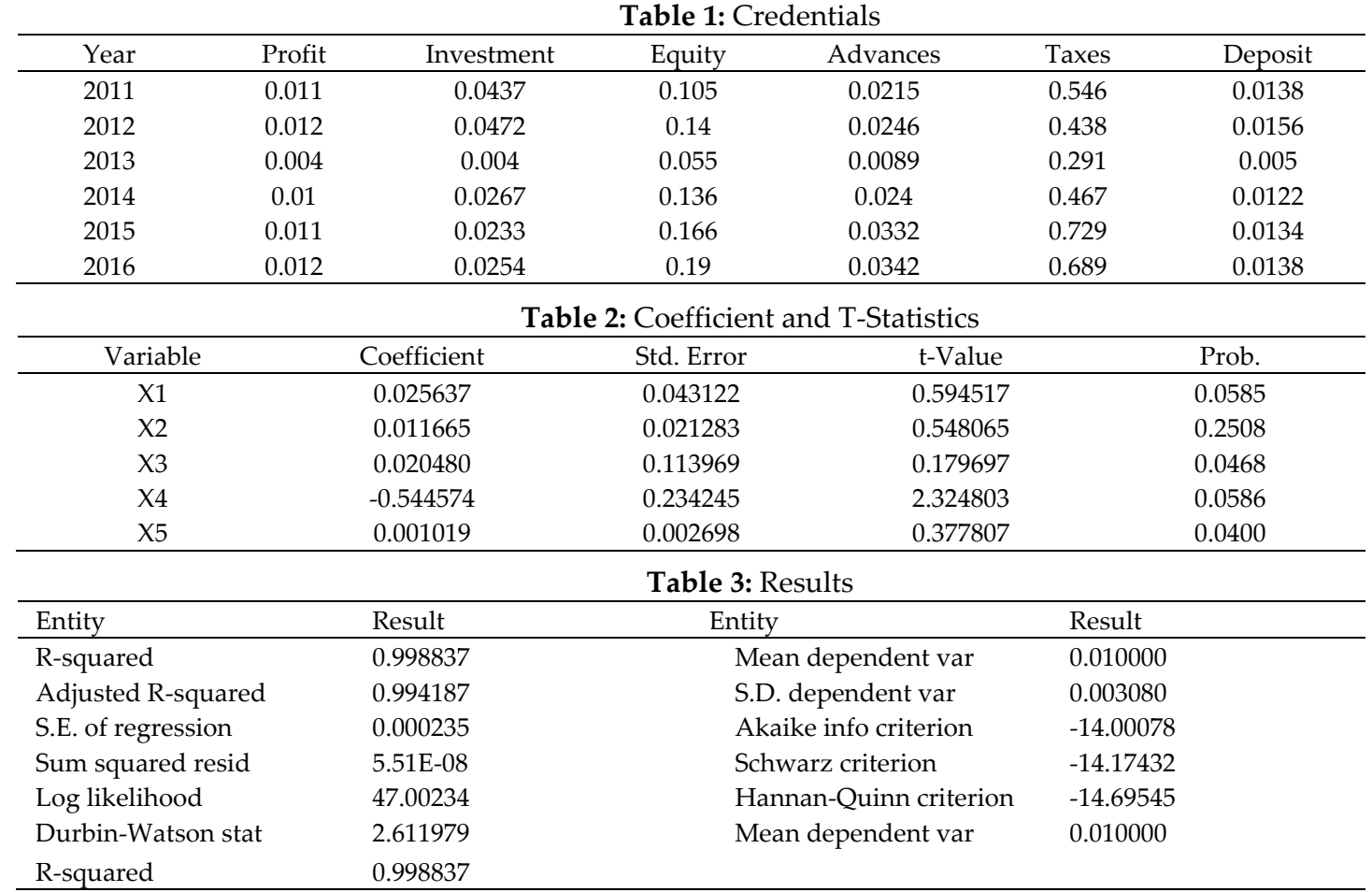




\section{Concluding Discussions}

The R-square shows the fitness of the model. R-square indicates that how much dependent variables explained the independent variables. Accordingly, in the above regression, R-square is 0.99 , which shows that independent variables (Advances, deposits, equity, investment \& taxes) explain 99\% of profitability. Pertaining to B1, the results show that $\mathrm{x}_{1}$, which is investment are statistically significant as the P-values is equal to 0.05 . Beta value indicates that every one-unit change brings two units to change in profitability. In connection to B2, the findings of this independent variable ( $\left.\mathrm{x}_{2}\right)$, which is equity is a statistically insignificant as P-values are greater than 0.05 there is more risk of occurrence, estimated results in future and the beta shows that, if every one unit change the outcomes changes one unit change in profitability. For B3, the outcomes show that $\mathrm{x}_{3}$, which is advances, is statistically significant as P-values is less than 0.05 , which is 0.046 and the beta value indicates that everyone element carries two units change in the profitability of the bank. Likewise, for B4, the results of this independent variable $\left(\mathrm{x}_{4}\right)$, which is taxes, are statistically significant as P-values is equal to 0.05 , and the beta value point outs that unit changes bring $50 \%$ decreases in the profitability of the bank. Similarly, for B5, the findings of these independent variables ( $\left.\mathrm{x}_{5}\right)$, which is deposits is statistically significant as P-values are less than 0.05 and the beta values show that every unit change brings 0.1 changes in profitability. About the Durbin-Watson statistical method, the DW statistical shows that there is no exist of autocorrelation problems in this model.

\subsection{Summary of the Findings}

The main objective of this study was to establish the impact of debt, investment, equity, advances on the profitability of banks of Pakistan. To achieve the objective, the researcher sampled the Muslim commercial bank of Pakistan (MCB) that exhibited the characteristics for the study. Secondary data was used in this study. Data was collected by the review of documents, annual reports of the sampled bank, and published books of accounts.

In this research, investment, equity, advances are independent variables and profitability is the dependent variable and the tool is selected for finding the relationship between variable is multiple regression method in Electronic views (e-views). The main findings of this research study were that leverage was found to have a positive effect on profitability, as illustrated by the table on Regression Co-efficient, and its significant at.000 level of significance as the p-value shows. Every one-unit change in leverage brings .049 unit changes in profitability as per beta values. The R-square is .99, which shows that this model is well defined and $82 \%$ of the profitability is expressed by independent variables.

\subsection{Research Limitations}

The time period was one of the limitations of this research study, and then data collection was most difficult as the study is based on secondary data; therefore, access and multiple websites were limiting this research. It took a lot of timer period to find useful data for this study. Access to data that was to be collected from various articles, books, and from different websites and can also be plagiarized, we had to be careful while selecting the data. Lake of experience writing a dissertation, it also becomes difficult when you are writing it first time, so this was also difficult to write it. Lake of fluency in the language, we had learned English as a second language in our school so, it was also difficult to write your dissertation in English. The research was based on secondary; it was very difficult to find reliable and prior research studies to your topic.

\section{References}

Ahmed, U., Khalid, N., Ammar, A., \& Shah, M. H. (2017). Assessing moderation of employee engagement on the relationship between work discretion, job clarity and business performance in the banking sector of Pakistan. Asian Economic and Financial Review, 7(12), 1197.

Alexiou, C., \& Sofoklis, V. (2009). Determinants of bank profitability: Evidence from the Greek banking sector. Economic annals, 54(182), 93-118. 
Annual Reports (2011-2016). Muslim commercial bank of Pakistan (MCB) annual financial reports (2011-2016). Retrieved from: http://www.sbp.org.pk/reports/annual/index.htm

Bashir, A. H. M. (2003). Determinants of profitability in Islamic banks: Some evidence from the Middle East. Islamic economic studies, 11(1).

Cole, R. A., \& Sokolyk, T. (2018). Debt financing, survival, and growth of start-up firms. Journal of Corporate Finance, 50, 609-625.

Gul, S., Irshad, F., \& Zaman, K. (2011). Factors Affecting Bank Profitability in Pakistan. Romanian Economic Journal, 14(39).

Galdeano, D., Ahmed, U., Fati, M., Rehan, R., \& Ahmed, A. (2019). Financial performance and corporate social responsibility in the banking sector of Bahrain: Can engagement moderate?. Management Science Letters, 9(10), 1529-1542.

Javaid, S., Anwar, J., Zaman, K., \& Gafoor, A. (2011). Determinants of bank profitability in Pakistan: Internal factor analysis. Mediterranean Journal of Social Sciences, 2(1).

Khawaja, M. I., Din, M. U., \& Siddiqui, R. (2006). Banking: Interest Spread, Inelastic Deposit Supply, and Mergers [with Comments]. The Pakistan Development Review, 1055-1070.

Khalid, N., Pahi, M. H., \& Ahmed, U. (2016). Loosing your best talent: Can leadership retain employees? The dilemma of the banking sector of Hyderabad Sindh, Pakistan: A mediation investigation. International Review of Management and Marketing, 6(3), 608-616.

Kraus, A., \& Litzenberger, R. H. (1973). A state-preference model of optimal financial leverage. The Journal of Finance, 28(4), 911-922.

Myers, S. C., \& Majluf, N. S. (1984). Corporate financing and investment decisions when firms have information that investors do not have, Journal of Financial Economics, 13(2), $187-221$.

Mugenda, Olive M. and Mugenda, Abel G. 1999. Research methods: Quantitative and qualitative approaches. Nairobi: ACTS Press

Obamuyi, T. M. (2013). DETERMINANTS OF BANKS'PROFITABILITY IN A DEVELOPING ECONOMY: EVIDENCE FROM NIGERIA. Organizations and Markets in Emerging Economies, 4(08), 97-111.

Pham, H. S. T., \& Nguyen, D. T. (2020). Debt financing and firm performance: The moderating role of board independence. Journal of General Management, 45(3), 141-151.

Raheman, A., \& Zulfiqar, B. Mustafa.(2007).Capital structure and profitability: A case of islamabad stock exchange". International Review of Business Research Papers, 3(5), 347-61.

Shaikh, S. H., Shaikh, H., \& Shaikh, S. (2019a). The impact of job satisfaction and job dissatisfaction on herzberg theory: A case study of meezan bank limited and national bank limited. International Journal of Business and Social Science, 10(6), 143-147.

Shaikh, S. H., Shaikh, H., \& Shaikh, S. (2019b). The Impact of Job Dissatisfaction on Extrinsic Factors and Employee Performance in Textile Industries. International Journal of Scientific and Research Publications (IJSRP), 9(6), 9-14.

Umrani, W. A., Kura, K. M., \& Ahmed, U. (2018). Corporate entrepreneurship and business performance. PSU Research Review, 2 (1), 59-80.

Umrani, W. A., Mahmood, R., \& Ahmed, U. (2016). Unveiling the direct effect of corporate entrepreneurship's dimensions on the business performance: a case of big five banks in Pakistan. Studies in Business and Economics, 11(1), 181-195.

C 2020 by the author(s). Published by Annals of Contemporary Developments in Management \& HR (ACDMHR), under the terms and conditions of the Creative Commons Attribution (CC BY) license which can be accessed at http://creativecommons.org/licenses/by/4.0. 